\title{
PENGARUH MOTIVASI, LINGKUNGAN KERJA DAN KEPEMIMPINAN TERHADAP KINERJA KARYAWAN PT SATU VISI EDUKASI
}

\author{
THE INFLUENCE OF MOTIVATION, WORK ENVIRONMENT AND LEADERSHIP ON \\ EMPLOYEE PERFORMANCE IN PT SATU VISI EDUKASI
}

\author{
Ramya Inggita Manikottama*), Lukman M Baga**), dan Aida Vitayala S Hubeis***) \\ *) Sekolah Bisnis, Institut Pertanian Bogor \\ Jl. Raya Pajajaran, Bogor 16151 \\ ${ }^{* *}$ Departemen Agribisnis, Fakultas Ekonomi dan Manajemen, Institut Pertanian Bogor \\ Jl. Kamper Kampus IPB Darmaga, Bogor 16680 \\ ${ }^{* * *}$ Departemen Sains Komunikasi dan Pengembangan Masyarakat, Fakultas Ekologi Manusia, Institut Pertanian Bogor \\ Jl. Kamper Kampus IPB Darmaga, Bogor 16680
}

\begin{abstract}
This research aimed to determine the effect of motivation, work environment, and leadership on employee performance in PT Satu Visi Edukasi. The methods utilized in this research were SEM (Structural Equation Model). The results of this research showed that motivation has a positive and significant relation to employee performance. Work environment has a negative and significant relation to independent variable of employee performance. Leadership has a positive and insignificant relation to employee performance. Motivation has the highest effect followed by the work environment and leadership. The best suggestion to improve employee performance is to increase employee motivation in obtaining achievements by giving rewards based on the employees'length of time in the company and work results in the company's upcoming programs.
\end{abstract}

Keywords: employee performance, leadership, motivation, work environment, SEM

\begin{abstract}
Abstrak: Penelitian ini bertujuan mengetahui pengaruh motivasi, lingkungan kerja dan kepemimpinan terhadap kinerja karyawan pada PT Satu Visi Edukasi. Metode yang digunakan dalam penelitian ini adalah SEM (Structural Equation Model). Hasil dari penelitian ini menunjukkan bahwa motivasi memiliki hubungan positif dan signifikan terhadap kinerja karyawan. Lingkungan kerja memiliki hubungan negatif dan signifikan terhadap variabel bebas yaitu kinerja karyawan. Kepemimpinan memiliki hubungan positif dan tidak signifikan terhadap kinerja karyawan. Motivasi memiliki pengaruh tertinggi yang diikuti oleh lingkungan kerja dan kepemimpinan. Saran terbaik untuk meningkatkan kinerja karyawan adalah meningkatkan motivasi karyawan untuk berprestasi melalui pemberian penghargaan berdasarkan lama karyawan bekerja dan hasil kerja karyawan di dalam program perusahaan kedepannya.
\end{abstract}

Kata kunci: kepemimpinan, kinerja karyawan, lingkungan kerja, motivasi, SEM

\footnotetext{
${ }^{1}$ Corresponding author:

Email: ramyainggita@gmail.com
} 


\section{PENDAHULUAN}

Persaingan global saat ini menuntut setiap perusahaan untuk tanggap dalam penyesuaian dinamika lingkungan bisnis. Persaingan global yang dihadapi tidak hanya pada lingkup bisnis namun hingga pada pemenuhan aspek sumber daya manusia. Bailey mengatakan keberhasilan bisnis didukung oleh kecanggihan teknologi dan finansial, tetapi di abad 21 lebih pada sumber daya manusia (Djati, 2000). Perusahaan yang secara efektif dapat mengelola karyawan memiliki tingkat profitabilitas tinggi. Demi mencapai tujuan tersebut pemimpin organisasi harus dapat menciptakan lingkungan kerja yang mendorong terciptanya motivasi karyawan. Sehingga dapat membantu karyawan mencapai sasaran perusahaan dengan adanya fungsi kepemimpinan yang baik.

PT Satu Visi Edukasi menilai Sumber Daya Manusia (SDM) sebagai aspek yang penting terutama dalam usaha peningkatan kinerja karyawan agar mampu bersaing dalam kompetisi global. Berbagai perubahan yang terjadi di dalam lingkup bisnis membuat manajemen PT Satu Visi Edukasi menyadari bahwa pengelolaan sumber daya manusia sebagai pilar penggerak tercapainya tujuan perusahaan. Sejak tahun 2015 hingga 2017 perusahaan menghadapi penurunan kinerja karyawan. Diketahui bahwa pencapaian rata-rata kinerja karyawan tidak mencapai target yang diharapkan perusahaan. Manajemen menduga bahwa penurunan kinerja perusahaan disebabkan oleh beberapa hal, salah satunya yaitu ketidakyamanan dalam lingkungan kerja. Hal ini dibuktikan dari adanya ketidakcocokan dalam berinteraksi dalam berkomunikasi antar karyawan. Selain itu, ditambah adanya aktifitas pembangunan proyek pembangunan jalan di jalan KH Sholeh Iskandar Bogor yang berdampak terhadap kebisingan di lingkungan kerja. Ketidakyamanan ini semakin dirasakan dengan memburuknya prasarana perusahaan.

Isu kepemimpinan juga dianggap memberikan pengaruh terhadap perubahan kinerja karyawan di PT Satu Visi Edukasi. Masalah ini tergambar dari pemimpin yang dinilai kurang mampu memformulasikan perencanaan SDM dan mengendalikan bawahan. Hal ini diketahui dari banyaknya karyawan yang tidak memiliki keinginan untuk meningkatkan kapasitas dirinya melalui sertifikasi selama tahun 2015-2017. Sertifikasi karyawan merupakan hal penting dalam perusahaan, dimana perusahaan menargetkan sertifikasi rata-rata karyawan meningkat minimal 50\%. Sejak tahun 2015 hingga 2017, diketahui bahwa sertifikasi karyawan tidak mencapai target yang diharapkan perusahaan. Meskipun pelatihan bersertifikasi sangat didukung oleh perusahaan sepenuhnya. Oleh sebab itu, manajemen percaya bahwa menurunnya kinerja karyawan disebabkan oleh rendahnya motivasi para karyawan di PT Satu Visi Edukasi. Berdasarkan latar belakang yang telah diuraikan PT Satu Visi Edukasi berupaya untuk meningkatkan kinerja karyawannya. Namun, ada beberapa faktor yang harus dikaji terlebih dahulu mengenai terhadap kinerja karyawannya. Faktorfaktor tersebut adalah motivasi, lingkungan kerja dan kepemimpinan. Ketiga faktor tersebut yang selama ini dianggap penting berdampak besar bagi kinerja karyawannya. Akan tetapi, hal tersebut belum dikaji lebih mendalam oleh PT Satu Visi Edukasi.

Kajian penelitian terdahulu yang relevan dengan motivasi, lingkungan kerja dan kepemimpinan terhadap kinerja karyawan di beberapa organisasi digunakan oleh peneliti sebagai dasar referensi dalam rangka mempertajam penelitian ini antara lain: Penelitian Suddin dan Sudarman (2010), penelitian ini bertujuan untuk menganalisis pengaruh kepemimpinan, motivasi, lingkungan kerja terhadap kinerja karyawan. Analisis statistik yang digunakan yaitu regresi. Penelitian ini menunjukkan bahwa tinggi dan rendahnya kinerja pegawai dipengaruhi oleh kepemimpinan, motivasi, dan lingkungan kerja. Penelitian Ardiyani dan Nugrahaeni (2017) menggunakan analisis statistik regresi linier berganda. Hasil penelitian menunjukkan bahwa lingkungan kerja berpengaruh positif dan signifikan terhadap kinerja karyawan. Kualitas kepemimpinan berpengaruh positif dan signifikan terhadap kinerja karyawan. Motivasi kerja berpengaruh positif dansignifikan terhadap kinerja karyawan. Penelitian Munparidi (2012) menggunakan analisis statistik regresi linier berganda. Hasil penelitian menunjukkan bahwa pelatihan dan lingkungan kerja berpengaruh positif dan signifikan terhadap kinerja karyawan. Kepemimpinan dan motivasi berpengaruh negatif dan tidak signifikan terhadap kinerja karyawan. Kepemimpinan, motivasi, pelatihan, dan lingkungan kerja berpengaruh secara simultan terhadap kinerja karyawan. Penelitian Parlinda dan Wahyudin (2009) menggunakan analisis statistik regresi linier berganda. Hasil penelitian menunjukkan bahwa pelatihan dan lingkungan kerja mempunyai pengaruh positif dan signifikan terhadap kinerja karyawan. Kepemimpinan dan motivasi berpengaruh negatif dan tidak signifikan pada kinerja karyawan. 
Perbedaan penelitian terdahulu dengan penelitian yang dilakukan dapat dilihat dari beberapa hal, yaitu obyek penelitian, tempat penelitian, metode analisis dan jumlah responden. Dalam penelitian ini, obyek penelitian yang digunakan adalah karyawan PT Satu Visi Edukasi. Metode analisis yang digunakan adalah Structural Equational Modelling-Partial Least Square (SEM-PLS).

Penelitian ini menggunakan tiga peubah, yaitu motivasi, lingkungan kerja, kepemimpinan dan kinerja karywan. Selanjutnya, indikator kinerja karyawan yang digunakan dalam penelitian ini diambil ukuran kinerja (Mitchell, 1978) yang terdiri dari lima komponen, yaitu kualitas kerja, ketepatan waktu, inisiatif, kemampuan dan komunikasi. Tujuan dari penelitian adalah menganalisis pengaruh lingkungan kerja terhadap kinerja karyawan PT Satu Visi Edukasi, menganalisis pengaruh lingkungan kerja terhadap motivasi karyawan PT Satu Visi Edukasi, menganalisis pengaruh kepemimpinan terhadap motivasi karyawan PT Satu Visi Edukasi, menganalisis pengaruh kepemimpinan terhadap kinerja karyawan PT Satu Visi Edukasi, dan menganalisis pengaruh motivasi karyawan terhadap kinerja karyawan PT Satu Visi Edukasi.

Penelitian difokuskan untuk mengukur pengaruh antara motivasi, lingkungan kerja dan kepemimpinan terhadap kinerja karyawan PT Satu Visi Edukasi. Responden dalam penelitian adalah seluruh karyawan kontrak PT Satu Visi Edukasi berjumlah 37 karyawan. Data yang dianalisis dalam penelitian adalah data yang diperoleh dari data primer dan sekunder. Metode analisis menggunakan dengan PLS dengan software SmartPLS versi 3.0.

\section{METODE PENELITIAN}

Penelitian dilaksanakan di PT Satu Visi Edukasi yang beralamat di gedung ILP Cimanggu Bogor, Jalan KH Sholeh Iskandar nomor 31, Kedung Jaya, Tanah Sareal, Bogor. Penelitian dilaksanakan selama empat bulan, yaitu pada bulan April 2018 hingga Juli 2018. Data yang digunakan pada penelitian adalah data primer dan data sekunder. Data yang digunakan pada penelitian adalah data primer dan data sekunder. Data primer biasanya diperoleh dari survei lapangan yang menggunakan semua metode pengumpulan data ordinal (Sugiyono, 2014). Data sekunder, yaitu data yang diperoleh dari laporan-laporan dan informasi lain yang bersumber dari literatur, dokumen dan informasi lain yang berhubungan dengan penulisan ini. Data primer secara khusus dikumpulkan untuk menjawab pertanyaan penelitian yang diperoleh langsung dari pengisian kuesioner oleh responden. Pengolahan hasil dari data primer yang berupa data kualitatif akan diolah menjadi data kuantitatif dengan skala likert. Sementara itu, scoring menggunakan angka satu sampai dengan empat hanya merupakan kode untuk mengetahui mana yang lebih tinggi dan mana yang lebih rendah. Penilaian dimulai pada sangat tidak baik dengan bobot terendah hingga sangat baik dengan bobot tertinggi. Penelitian ini merupakan penelitian deskriptif kuantitatif dan analisis kuantitatif peubah seperti motivasi, lingkungan kerja, kepemimpinan dan kinerja karyawan di PT Satu Visi Edukasi. Metode analisis menggunakan SEM dengan pendekatan PLS, dimana perhitungan statistiknya dilakukan dengan software SmartPLS versi 3.0. Menurut Ghozali (2011), PLS merupakan metode analisis yang kuat yang tidak memiliki dasar dengan banyak asumsi. PLS adalah jenis analisis multivariat (multivariate analysis) dalam ilmu sosial. Tujuan analisis multivariat, yaitu konfirmasi dan eksplorasi (Hair et al. 2013).

Tahap analisis dalam PLS dimulai dari pengukuran model (outer model), struktur model (inner model) dan pengujian hipotesis. Penilaian outer model dimulai dengan penentuan convergent validity untuk masingmasing konstruk. Convergent validity digunakan untuk mengukur validitas dari tiap indikator. Nilai outer loading dikatakan valid jika berkorelasi lebih dari 0,5 dengan variabel yang diukur. Discriminant validity merupakan derajat kesesuaian antara variabel atau atribut yang diukur oleh alat ukur dan konsep teoritis. Pada model PLS reflektif discriminant validity dapat digunakan beberapa ukuran seperti cross loading, rho_a dan composite realibility. Discriminant validity dinilai berdasarkan cross loading pengukuran dengan konstruk. Cross loading digunakan untuk mengetahui hubungan antara variabel dengan indikator. Discriminant validity dapat juga diukur dengan membandingkan nilai rho_a suatu konstruk. Rho_a digunakan untuk menguji reabilitas dari sebuah model yang diteliti. Nilai batas reliabilitas rho_a adalah 0,70 (Ghozali, 2011). Discriminant validity juga dapat dilihat dari nilai composite reliability dari konstruk. Koefisien composite reliability diperkenalkan oleh Raykov (1997) dengan menggunakan analisis faktor konfirmatori dalam 
pendekatan model persamaan struktural. Penggunaan composite realibility disetujui memiliki keunggulan yang lebih baik dari pada realibility biasanya. Nilai batas composite reliability yang diterima untuk tingkat reabilitas komposit adalah 0.6.

Inner model menggambarkan hubungan antar variabel laten. Inner model ingin melihat hubungan antar konstruk dan nilai signifikansi serta nilai $\mathrm{R}$-square $\left(\mathrm{R}^{2}\right)$. Pada inner model dilakukan tahap evaluasi terhadap persentase varian melalui nilai $\mathrm{R}^{2}$ ( $\mathrm{R}$-square). Penggunaan nilai $\mathrm{R}^{2}$ ( $\mathrm{R}$-square) untuk mengambarkan sejauh mana model dapat digambarkan melalui tiap variabel yang digunakan. Model PLS dinilai berawal dari melihat nilai R-square untuk variabel laten dependent. Nilai R-square digunakan untuk menilai pengaruh variabel laten independent tertentu terhadap variabel laten dependent. Koefisien determinasi $\mathrm{R}^{2}$ digunakan untuk melihat sejauh mana variabel eksogen mampu menerangkan keragaman variabel terikatnya. Nilai $\mathrm{R}^{2}$ digunakan untuk mengukur tingkat keberhasilan model yang digunakan dalam memprediksi nilai variabel terikatnya. Koefisien determinasi memiliki nilai antara nol sampai satu $(0 \leq$ $\mathrm{R}^{2} \leq 1$ ). Koefisien determinasi bernilai nol berarti tidak ada hubungan antara variabel bebas dengan variabel terikat. Sebaliknya, nilai koefisien determinasi bernilai satu menunjukkan kecocokan sempurna dari ketepatan model (Ghozali, 2011).

Analisa korelasi digunakan untuk mengetahui arah dari tiap hubungan variabel. Sementara signifikansi digunakan sebagai informasi mengenai kuat atau lemahnya hubungan dari tiap variabel. Pengujian hipotesis (resampling boostraping) yaitu menguji hipotesis dengan melihat besarnya nilai t-statistik. Signifikansi parameter yang diestimasi memberikan informasi yang sangat berguna mengenai hubungan antar variabel penelitian. Penelitian ini menggunakan empat variabel yang diteliti, yaitu motivasi, lingkungan kerja, kepemimpinan dan kinerja karyawan, dengan menggunakan taraf nyata sebesar 5\%. Batas untuk menolak dan menerima hipotesis yang diajukan adalah $>1,96$, jika nilai $t$ berada pada rentang nilai $<1,96$ maka hipotesis akan ditolak.

Kerangka pikir penelitian (Gambar 1) berfungsi sebagai penuntun alur pikir dan sekaligus sebagai dasar dalam penelitian. Penelitian dimulai dari masalah penelitian, yaitu ketidaknyamanan lingkungan kerja, rendahnya motivasi karyawan dan ketidakefektifan fungsi pemimpin. Sesuai dengan masalah tersebut maka penelitian menggunakan dasar teori jenis lingkungan kerja (Sedarmayanti, 2010), teori dua faktor Hezberg (Bangun, 2012), fungsi kepemimpinan (Adair, 2006) dan ukuran kinerja (Mitchell, 1978). Penelitian menggunakan metode analisis PLS yang kemudian akan menghasilkan implikasi manajerial.

\section{Hipotesis Penelitian}

Berdasarkan kerangka pikir penelitian maka hipotesis penelitian yang diajukan adalah sebagai berikut:

1. H1: Lingkungan kerja berpengaruh positif dan signifikan terhadap kinerja karyawan. Hipotesis ini didukung oleh Suddin dan Sudarman (2010), Ardiyani dan Nugrahaeni (2017), Munparidi (2012), Parlinda dan Wahyudin (2009), Moulana et al. (2017), Prakoso et al. (2014), Gardjito et al. (2014), yang berpendapat bahwa lingkungan kerja berpengaruh positif dan signifikan terhadap kinerja karyawan. Berbeda halnya dengan anggapan dari Sukmasari (2015), Ernawati dan Ambarini (2010), Arianto (2013) yang menyatakan bahwa lingkungan kerja berpengaruh negatif dan tidak signifikan terhadap kinerja karyawan.

2. H2: Lingkungan kerja berpengaruh positif dan signifikan terhadap motivasi karyawan. Hipotesis ini didukung oleh Moulana et al. (2017) yang menyatakan bahwa lingkungan kerja berpengaruh positif dan signifikan terhadap motivasi. Berbeda halnya dengan anggapan dari Ernawati dan Ambarini (2010) yang berpendapat bahwa lingkungan kerja berpengaruh negatif dan tidak signifikan terhadap motivasi.

3. H3: Kepemimpinan berpengaruh positif dan signifikan terhadap motivasi karyawan. Hipotesis ini didukung oleh Renat (2013), Mahendra dan Brahmasari (2014) yang menyatakan bahwa kepemimpinan berpengaruh positif dan signifikan terhadap motivasi. Berbeda halnya dengan anggapan dari Munparidi (2012) yang berpendapat bahwa kepemimpinan berpengaruh negatif dan tidak signifikan terhadap motivasi.

4. H4: Kepemimpinan berpengaruh positif dan signifikan terhadap kinerja karyawan. Hipotesis ini didukung oleh Suddin dan Sudarman (2010), Ardiyani dan Nugrahaeni (2017), Renat (2013), Baki (2012), Budiwati (2011), Elina (2011), Kustrianingsih et al. (2016), dan Cahyono (2012), yang menyatakan bahwa kepemimpinan berpengaruh positif dan signifikan terhadap kinerja 
karyawan. Berbeda halnya dengan anggapan dari Munparidi (2012), Parlinda dan Wahyudin (2009), Sukmasari (2015), Mahendra dan Brahmasari (2014) yang menyatakan bahwa kepemimpinan berpengaruh negatif dan tidak signifikan terhadap kinerja karyawan.

5. H5: Motivasi karyawan berpengaruh positif dan signifikan terhadap kinerja karyawan. Hipotesis ini didukung oleh Suddin dan Sudarman (2010), Ardiyani dan Nugrahaeni (2017), Prakoso, Astuti dan Ruhana (2014), Gardjito, et al. (2014), Renat (2013), Baki (2012), Budiwati (2011), Elina (2011), Kustrianingsih et al. (2016), Sukmasari (2015), Mahendra dan Brahmasari (2014), dan Cahyono (2012), yang menyatakan bahwa motivasi berpengaruh positif dan signifikan terhadap kinerja karyawan. Berbeda halnya dengan anggapan dari Munparidi (2012), Parlinda dan Wahyudin (2009), Ernawati dan Ambarini (2010) yang berpendapat bahwa motivasi berpengaruh negatif dan tidak signifikan terhadap kinerja karyawan.

\section{HASIL}

\section{Analisis Model Struktural}

Model struktural digunakan untuk mendeskripsikan hubungan dari tiap variabel ke variabel lain serta indikator ke variabel. Adapun model struktural PLS dalam penelitian ini sesuai dengan Gambar 2.

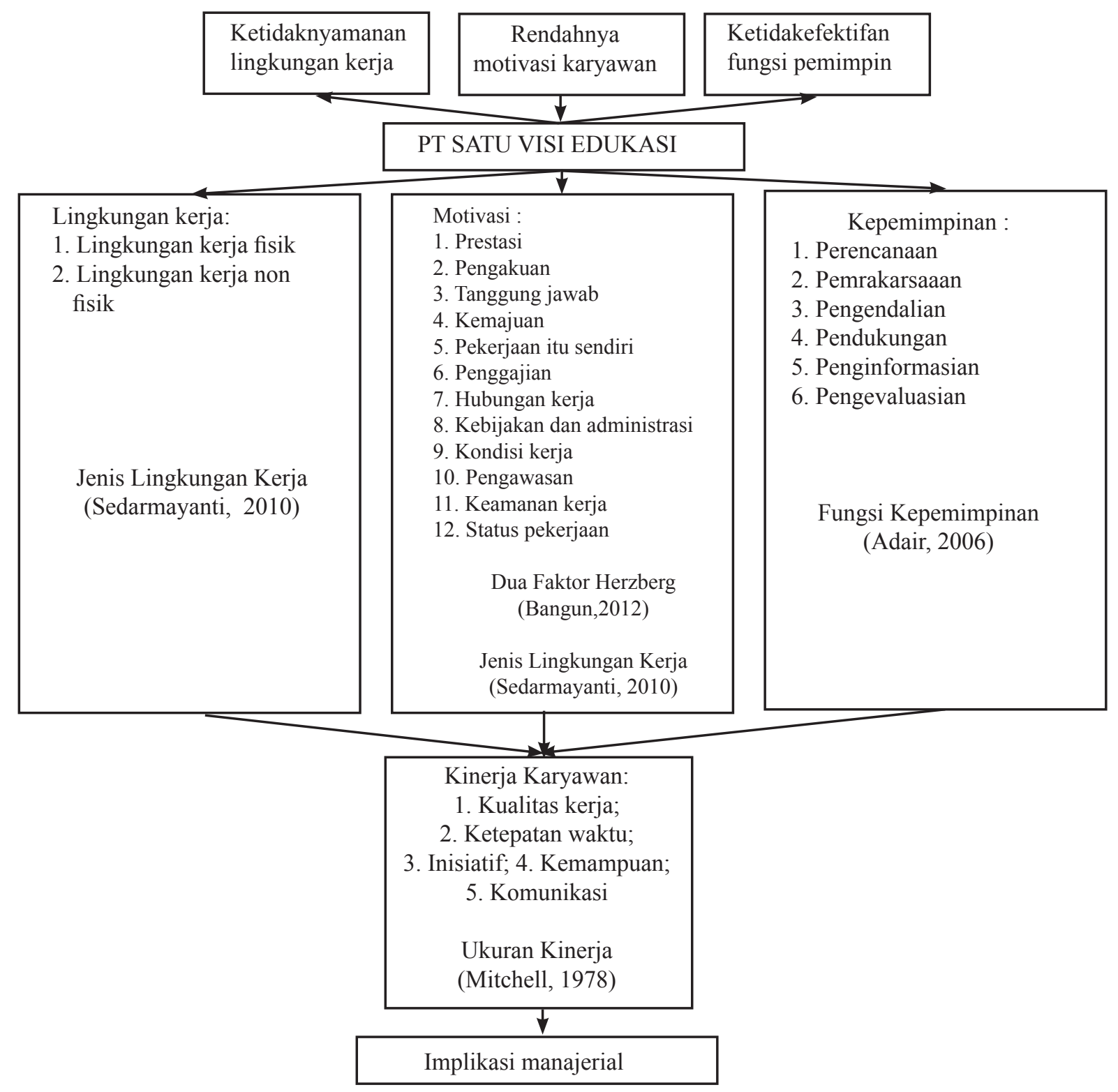

Gambar 1. Kerangka pemikiran penelitian 


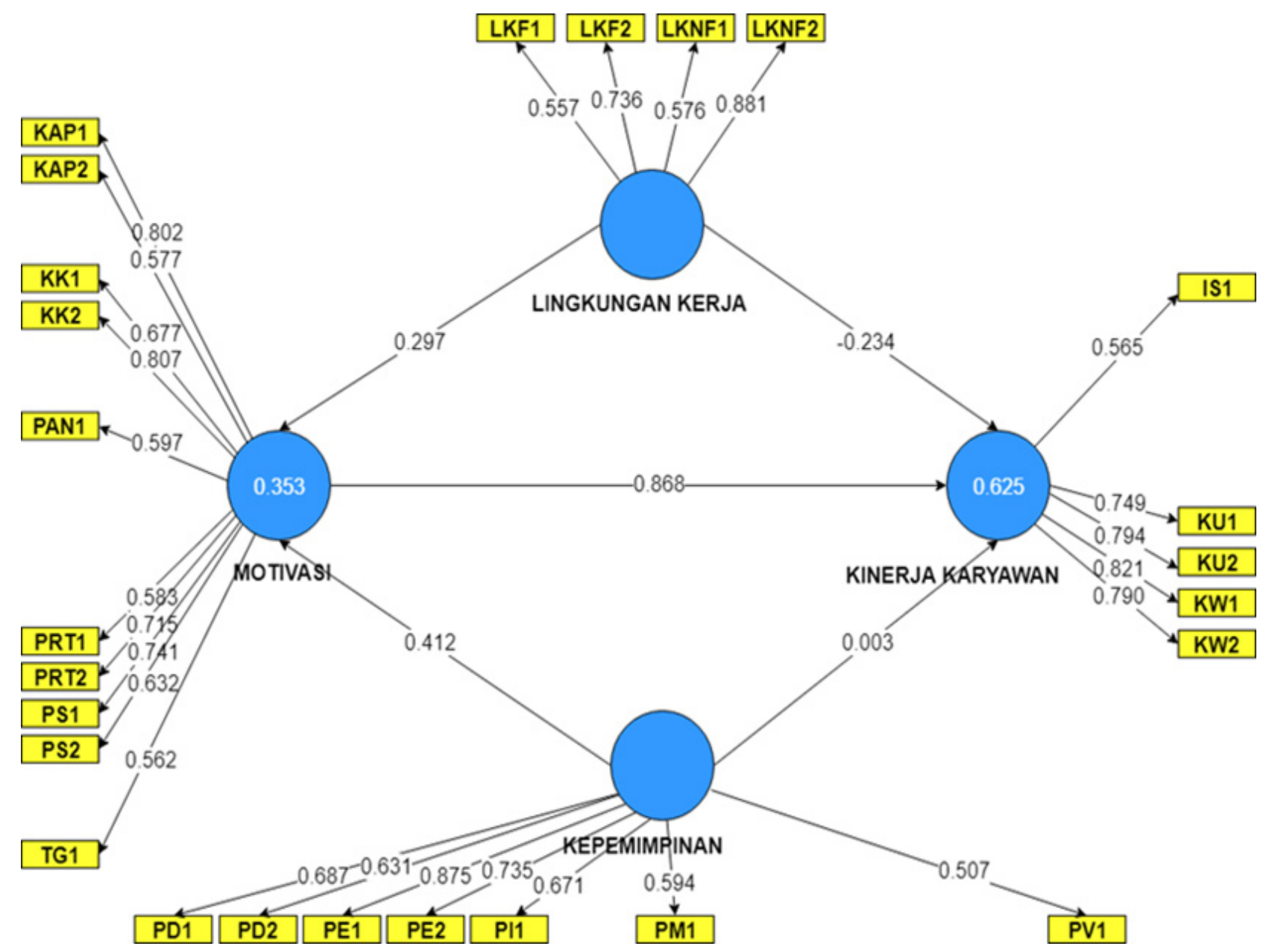

Lingkungan Kerja

Ketersediaan fungsi prasarana (LKF1), tingkat kebisingan rendah (LKF2), dukungan antar karyawan (LKNF1) dan interaksi harmonis antar karyawan (LKNF2)
Motivasi:

Pemberian penghargaan hasil (PRT1), pemberian penghargaan lama bekerja (PRT2), pencapaian target (TG1), kebanggaan pada pekerjaan (PS1), kesesuaian kompetensi pekerjaan (PS2), kepuasan peraturan perusahaan (KAP1), penyesuaian kebijakan perusahaan (KAP2), kejelasan status karyawan (KK1), pemberian jaminan kesehatan (KK2), dan kenyamanan pengawasan atasan (PAN1).
Kepemimpinan:

Kemampuan evaluasi kelayakan gagasan (PV1), kemudahan akses komunikasi (PI1), kemampuan pemberian solusi masalah (PD1), kemampuan pemberian motivasi bawahan (PD2), kemampuan pemberian kewenangan (PE1), kemampuan penyatuan kepentingan (PE2), dan kemampuan pengambilan keputusan (PM1).
Kinerja Karyawan:

Pencapaian standar kualitas (KU1), Penilaian hasil kerja (KU2), Kesesuaian rencana dengan hasil kerja (KW1), Kedisiplinan penyelesaian waktu pekerjaan (KW2), dan pemberian ide pekerjaan (IS1).

Gambar 2. Model Stuktural PLS

\section{Pengujian Outer Model}

Convergent validity digunakan untuk mengukur validitas dari tiap indikator. Pada penelitian ini diketahui 4 indikator lingkungan kerja yang seluruhnya valid, 24 indikator motivasi yang 10 valid dan 14 tidak valid, 12 indikator kepemimpinan yang 7 valid dan 5 tidak valid, 12 indikator kinerja karyawan yang 5 valid dan 7 tidak valid. Indikator yang valid dinyatakan sudah sesuai dengan kriteria tujuan yang diharapkan. Sementara itu, indikator yang tidak valid dinyatakan tidak sesuai dengan kriteria tujuan yang diharapkan. Discriminant validity digunakan untuk derajat kesesuaian antara variabel atau atribut yang diukur oleh alat ukur dan konsep teoritis. Dalam discriminant validity terdapat tiga uji yaitu cross loading, rho_a, dan composite reliability. 


\section{Cross Loading}

Cross loading merupakan hubungan antara variabel dengan indikator yang digunakan dalam menentukan hubungannya. Hasil penelitian ini diketahui nilai tertinggi indikator lingkungan kerja pada interaksi harmonis antar karyawan $(0,881)$. Nilai tertinggi indikator motivasi pada pemberian jaminan kesehatan $(0,807)$. Nilai tertinggi indikator kepemimpinan pada kemampuan pemberian kewenangan $(0,875)$. Nilai tertinggi indikator kinerja karyawan pada kesesuaian rencana dengan hasil kerja $(0,821)$.

\section{Rho_a}

Rho_a digunakan untuk menguji reabilitas dari sebuah model yang diteliti. Adapun hasil uji rho_a disajikan pada Tabel 1. Berdasarkan hasil yang telah disajikan dalam Tabel 1, dengan nilai rho_a $>0.7$ semua model pengukuran pada penelitian ini memiliki nilai reliabilitas individual yang baik. Uji rho_a juga digunakan pada penelitian Atmojo et al. (2016) yang memiliki hasil nilai reliabilitas yang sesuai dengan Goodness of Fit (GOF) yang memiliki nilai batas 0,7 .

\section{Reliabilitas Komposit}

Koefisien reliabilitas komposit (composite reliability) dikembangkan oleh Raykov (1997) dengan menggunakan analisis faktor konfirmatori dalam pendekatan model persamaan struktural. Adapun hasil reliabilitas komposit disajikan pada Tabel 2 .
Berdasarkan Tabel 2 diketahui bahwa nilai composite realibility dari setiap variabel diketahui seluruhnya telah dinyatakan reliabel karena seluruh variabel memiliki nilai diatas 0,6 . Berdasarkan hal tersebut menandakan setiap variabel dapat dinyatakan konsisten dalam menghasilkan nilai terhadap modelnya.

\section{Pengujian Inner Model}

\section{Nilai R2 (R-square)}

Penggunaan nilai $\mathrm{R}^{2}$ (R-square) digunakan untuk mengambarkan sejauh mana model dapat digambarkan melalui tiap variabel yang digunakan. Adapun hasil nilai $\mathrm{R}^{2}$ (R-square) disajikan pada Tabel 3. Berdasarkan Tabel 3 diketahui bahwa variabel kinerja karyawan dapat mengambarkan model sebenarnya $62,5 \%$, dimana sisanya $37,5 \%$ dapat digambarkan oleh variabel di luar yang diteliti. Selain itu, diketahui bahwa variabel motivasi memiliki nilai paling kecil yaitu 0,353 dari skala 1 yang artinya variabel motivasi hanya mampu mengambarkan model $35,3 \%$ dan sisanya $64,7 \%$ digambarkan dari luar model.

\section{Korelasi dan Signifikansi Model}

Analisis korelasi digunakan untuk mengetahui arah dari tiap hubungan variabel. Sementara itu, signifikansi digunakan sebagai informasi mengenai kuat atau lemahnya hubungan dari tiap variabel. Adapun hasil korelasi dan signifikansi model disajikan pada Tabel 4.

Tabel 1. Nilai rho_a variabel tiap variabel

\begin{tabular}{lccc}
\hline Variabel & Rho_A & Goodnes of Fit (GOF) & Keterangan \\
\hline Kepemimpinan & 0,87 & 0,7 & Reliabel \\
Kinerja karyawan & 0,822 & 0,7 & Reliabel \\
Lingkungan kerja & 0,758 & 0,7 & Reliabel \\
Motivasi & 0,883 & 0,7 & Reliabel \\
\hline
\end{tabular}

Tabel 2. Nilai reliabilitas komposit tiap variabel

\begin{tabular}{lccc}
\hline Variabel & Reliabilitas Komposit & Goodnes of Fit (GOF) & Keterangan \\
\hline Kepemimpinan & 0,854 & 0,6 & Reliabel \\
Kinerja karyawan & 0,863 & 0,6 & Reliabel \\
Lingkungan kerja & 0,788 & 0,6 & Reliabel \\
Motivasi & 0,892 & 0,6 & Reliabel \\
\hline
\end{tabular}


Tabel 3. Nilai R² (R-square) variabel

\begin{tabular}{lcccc}
\hline Variabel & R Square & R Square Adjusted & Goodness of Fit (GOF) & Keterangan \\
\hline Kinerja karyawan & 0,625 & 0,591 & 0,5 & Tinggi \\
Motivasi & 0,353 & 0,315 & 0,5 & Kecil \\
\hline
\end{tabular}

Tabel 4. Hasil analisis korelasi dan signifikansi model tiap variabel

\begin{tabular}{lcclc}
\hline Hubungan & Original Sample & T Statistik & Keterangan & Keputusan \\
\hline Lingkungan kerja $\rightarrow$ Kinerja karyawan & $-0,234$ & 2,206 & Negatif dan signifikan & Tolak H1 \\
Lingkungan kerja $\rightarrow$ Motivasi & 0,297 & 2,446 & Positif dan signifikan & Terima H2 \\
Kepemimpinan $\rightarrow$ Motivasi & 0,412 & 2,843 & Positif dan signifikan & Terima H3 \\
Kepemimpinan $\rightarrow$ Kinerja karyawan & 0,003 & 0,022 & Positif dan tidak signifikan & Tolak H4 \\
Motivasi $\rightarrow$ Kinerja karyawan & 0,868 & 8,740 & Positif dan signifikan & Terima H5 \\
\hline
\end{tabular}

\section{Pengaruh Lingkungan Kerja Terhadap Kinerja Karyawan}

Hasil pengujian yang ditunjukkan Tabel 4, didapat bahwa lingkungan kerja memiliki hubungan negatif $(-0,234)$ dan signifikan $(2,206>1,96)$ terhadap kinerja karyawan maka $\mathrm{H} 1$ ditolak. Hasil penelitian berbeda dengan penelitian terdahulu yang dikemukakan oleh Suddin dan Sudarman (2010), Ardiyani dan Nugrahaeni (2017), Munparidi (2012), Parlinda dan Wahyudin (2009), Moulana et al. (2017), Prakoso et al. (2014), dan Gardjito et al. (2014). Hasil dari penelitian tersebut membuktikan bahwa lingkungan kerja memiliki pengaruh positif dan signifikan terhadap kinerja karyawan. Perbedaan hasil penelitian dari kajian terdahulu dengan penelitian ini disebabkan oleh perbedaan kondisi tempat penelitian, metode analisis dan jumlah responden. Dengan demikian dapat diartikan bahwa lingkungan kerja yang tidak baik akan membuat kinerja karyawan menurun. Perusahaan dapat memperbaiki lingkungan kerja fisik dengan menjaga tingkat kebisingan yang rendah di gedung kantor dikarenakan banyaknya aktivitas proyek pembangunan jalan yang mengganggu aktivitas bekerja dan belajar.

\section{Pengaruh Lingkungan Kerja Terhadap Motivasi}

Hasil pengujian yang ditunjukkan Tabel 4, didapat bahwa lingkungan kerja memiliki hubungan positif $(0,297)$ dan signifikan $(2,446>1,96)$ terhadap motivasi maka $\mathrm{H} 2$ diterima. Hal ini menguatkan penelitian terdahulu oleh Moulana et al. (2017). Hasil penelitian tersebut membuktikan bahwa lingkungan kerja memiliki pengaruh positif dan signifikan terhadap motivasi. Dengan demikian, dapat disimpulkan bahwa variabel lingkungan kerja sudah sesuai dengan harapan manajemen maka dapat diartikan bahwa semakin baik lingkungan kerja akan dapat meningkatkan motivasi karyawan secara signifikan. Sebaiknya manajemen dapat meningkatkan lingkungan kerja nonfisik dengan meningkatkan interaksi harmonis antar karyawan dan dukungan antar karyawan yang terbukti dapat meningkatkan motivasi karyawan.

\section{Pengaruh kepemimpinan terhadap motivasi}

Hasil pengujian yang ditunjukkan Tabel4, didapatbahwa kepemimpinan memiliki hubungan positif $(0,412)$ dan signifikan $(2,843>1,96)$ terhadap motivasi maka $\mathrm{H} 3$ diterima. Hal ini menguatkan penelitian terdahulu oleh Renat (2013) dan Mahendra dan Brahmasari (2014) yang membuktikan bahwa kepemimpinan memiliki pengaruh positif dan signifikan terhadap motivasi. Maka dapat disimpulkan bahwa variabel kepemimpinan sudah sesuai dengan harapan manajemen. Dengan demikian, dapat diartikan semakin tinggi efektivitas fungsi kepemimpinan dapat meningkatkan motivasi karyawan secara signifikan. Sebaiknya manajemen meningkatkan fungsi penginformasian kepada karyawannya dengan memberikan kemudahan akses komunikasi.

\section{Pengaruh Kepemimpinan Terhadap Kinerja Karyawan}

Hasil pengujian yang ditunjukkan Tabel 4, didapat bahwa kepemimpinan memiliki hubungan positif $(0,003)$ dan tidak signifikan $(0,022<1,96)$ terhadap kinerja karyawan maka $\mathrm{H} 4$ ditolak. Hasil penelitian berbeda dengan penelitian terdahulu yang dikemukakan oleh Suddin dan Sudarman (2010), Ardiyani dan Nugrahaeni (2017), Renat (2013), Baki (2012), Budiwati (2011), Elina (2011), Kustrianingsih et al. (2016), dan Cahyono (2012) yang membuktikan bahwa kepemimpinan memiliki pengaruh positif dan signifikan 
terhadap kinerja karyawan. Perbedaan hasil penelitian dari kajian terdahulu dengan penelitian ini disebabkan oleh perbedaan tempat penelitian, metode analisis dan jumlah responden. Maka dapat disimpulkan bahwa variabel kepemimpinan sudah sesuai dengan harapan manajemen dan tidak menjadi prioritas manajemen untuk diperbaiki. Dengan demikian, dapat diartikan bahwa kepemimpinan yang berfungsi efektif tidak berpengaruh secara langsung pada peningkatan kinerja karyawan.

\section{Pengaruh Motivasi Terhadap Kinerja Karyawan}

Hasil pengujian yang ditunjukkan Tabel 4, didapat bahwa motivasi memiliki hubungan positif $(0,868)$ dan signifikan $(8,740>1,96)$ terhadapkinerja karyawan maka H5 diterima. Hal ini menguatkan penelitian terdahulu oleh Suddin dan Sudarman (2010), Ardiyani dan Nugrahaeni (2017), Prakoso, Astuti dan Ruhana (2014), Gardjito et al. (2014), Renat (2013), Baki (2012), Budiwati (2011), Elina (2011), Kustrianingsih et al. (2016), Sukmasari (2015), Mahendra dan Brahmasari (2014), dan Cahyono (2012), yang membuktikan bahwa motivasi memiliki pengaruh positif dan signifikan terhadap kinerja karyawan. Maka dapat disimpulkan bahwa variabel motivasi sudah sesuai dengan harapan. Dengan demikian, dapat diartikan bahwa semakin tinggi motivasi karyawan dapat meningkatkan kinerja karyawan secara signifikan. Manajemen diharapkan dapat meningkatkan faktor prestasi melalui pemberian prestasi berdasarkan penghargaan hasil kerja dan penghargaan lama bekerja.

\section{Implikasi Manajerial}

Beberapa hal penting yang dapat dijadikan implikasi manjerial bagi manajemen PT Satu Visi Edukasi. Adapun diantaranya: motivasi dianggap sebagai hal penting oleh para manajer dalam meningkatkan kinerja karyawan. Hal ini terkait dari aspek dasar motivasi dari karyawan yang berkeinginan untuk dapat terus berprestasi pada setiap aktivitas pekerjaannya. Selain itu, perusahaan juga menuntut karyawan untuk selalu memotivasi diri untuk bertanggung jawab dalam mencapai target yang telah ditetapkan. Ketepatan kompetensi yang ditetapkan oleh perusahaan membuat karyawan merasa bangga dengan pekerjaannya yang sesuai dengan dasar pendidikannya. Perusahaan diharapkan dapat memberikan aturan kerja yang sesuai dengan kondisi project. Aturan kerja yang telah sesuai juga diketahui memberikan pengaruh terhadap meningkatnya motivasi dari karyawan. Pengawasan pekerjaan pada karyawan yang dilakukan atasan dianggap dapat memberikan stimulus guna meningkatkan kinerja karyawan. Tingginya motivasi karyawan juga dipengaruhi dari kejelasan status karyawan serta pemberian jaminan kesehatan yang layak. Jika hal ini dapat dilakukan maka motivasi dari karyawan dapat meningkat sehingga kinerja karyawan akan meningkat yang pada akhirnya berdampak pada perusahaan.

Fungsi kepemimpinan merupakan bagian penting bagi perusahaan. Diketahui kepemimpinan lebih berdampak pada peningkatan motivasi dari pada peningkatan kinerja karyawan. Hal ini membuat para manajer perlu berfokus pada peningkatan motivasi melalui beberapa hal seperti pengendalian karyawan dengan cara pemberian wewenang yang lebih baik serta menyatukan berbagai kepentingan dari karyawan. Selain itu, manajer dapat meningkatkan kepemimpinan melalui evaluasi dari setiap gagasan yang diberikan. Kemudahan berkomunikasi dengan atasan dianggap memberikan dampak terhadap meningkatnya motivasi karyawan sehingga solusi dari suatu permasalahan dapat diimplementasikan dengan lebih cepat maka pimpinan juga dituntut untuk lebih aktif dalam meningkatkan motivasi karyawan.

Lingkungan kerja merupakan bagian yang tidak dapat dipisahkan dalam perusahaan, dimana lingkungan kerja terdiri dari dua bagian yaitu lingkungan fisik dan non fisik. Diketahui bahwa saat proses penelitian di lingkungan perusahaan sedang berlangsung adanya aktivitas proyek pembangunan pembangunan jalan. Proyek ini berdampak pada menurunnya fungsi prasarana seperti kantor dan terjadinya kegaduhan saat jam kantor. Lingkungan fisik khususnya yang bersumber dari eksternal tidak dapat dikelola secara langsung maka para manajer melakukan peningkatan melalui pemberian dukungan terhadap karyawan. Pemberian dukungan antar karyawan dipercaya dapat meningkatkan motivasi dari setiap karyawan. Selain itu interaksi harmonis antar karyawan juga dipercaya dapat diambil sebagai solusi dalam meningkatkan motivasi karyawan. 


\section{KESIMPULAN DAN SARAN}

\section{Kesimpulan}

Lingkungan kerja berpengaruh negatif dan signifikan terhadap kinerja karyawan PT Satu Visi Edukasi. Peranan lingkungan kerja secara langsung tidak memiliki pengaruh baik terhadap kinerja karyawan, namun dapat berpengaruh jika melalui motivasi. Lingkungan kerja berpengaruh positif dan signifikan terhadap motivasi PT Satu Visi Edukasi. Peranan lingkungan kerja diketahui memiliki peranan penting dalam peningkatkan motivasi karyawan. Lingkungan kerja dianggap dapat meningkatkan motivasi dari para karyawan. Kepemimpinan berpengaruh positif dan signifikan terhadap motivasi PT Satu Visi Edukasi. Kepemimpinan diketahui memiliki peranan besar bagi motivasi karyawan. Kepemimpinan dianggap dapat meningkatkan motivasi dari para karyawan. Kepemimpinan berpengaruh positif dan tidak signifikan terhadap kinerja karyawan PT Satu Visi Edukasi. Fungsi kepemimpinan secara langsung tidak memiliki pengaruh langsung terhadap kinerja karyawan. Namun, dapat berpengaruh jika melalui motivasi. Motivasi berpengaruh positif dan signifikan terhadap kinerja karyawan PT Satu Visi Edukasi. Motivasi berperan penting dalam peningkatkan kinerja karyawan. Hal ini perlu disadari oleh manajemen guna menjaga serta terus meningkatkan motivasi dalam bekerja.

\section{Saran}

Perusahaan sebaiknya berfokus pada penguatan dan pengembanganfaktormotivasiuntukberprestasimelalui pemberian penghargaan berdasarkan lama karyawan bekerja dan hasil kerja karyawan di dalam program perusahaan kedepannya, dikarenakan berdasarkan hasil faktor tersebut secara signifikan mempengaruhi kinerja karyawan PT Satu Visi Edukasi. Sebaiknya penelitian selanjutnya mempertimbangkan teori dan variabelvariabel lain yang berpotensi memiliki pengaruh terhadap kinerja karyawan, diantaranya kepuasan kerja, pelatihan, budaya organisasi dan disiplin kerja. Disamping itu jumlah sampel penelitian sebaiknya ditambah, termasuk lokasi penelitian diperluas sehingga diharapkan dapat diperoleh hasil yang lebih representatif.

\section{DAFTAR PUSTAKA}

Ardiyani NA, Nugrahaeni R. 2017. Analisis pengaruh lingkungan kerja, kualitas, kepemimpinan dan motivasi kerja terhadap kinerja karyawan (studi pada PT PLN Persero Kantor Distribusi Jateng dan D.I.Yogyakarta). Diponegoro Journal of Management 6(4):1-10.

Arianto. 2013. Pengaruh kedisiplinan, lingkungan kerja dan budaya kerja terhadap kinerja tenaga pengajar. Jurnal Economia 9(2):191-200.

Atmojo RNP, Nurhasan MB, Amanda KC, Melisa J. 2016. Penilaian penerimaan pengguna pada sistem manajemen pengetahuan dengan metoda UTAUT. Ultima InfoSys 7(2):65-74. https://doi. org/10.31937/si.v7i2.542.

Baki U. 2012. Analisis pengaruh kepemimpinan dan motivasi terhadap kinerja pegawai pada Dinas Kesehatan Kota Bandar Lampung. Jurnal Organisasi dan Manajemen 2(1):10-17. https:// doi.org/10.21009/jmp.02103.

Bangun W. 2012. Manajemen Sumber Daya Manusia. Jakarta: Erlangga.

Budiwati H. 2011. Dimensi kepemimpinan dan motivasi kerja terhadap kinerja pegawai koperasi karyawan PT Pindad Persero. Jurnal Penelitian Ilmu Ekonomi 1(1):49-55.

Cahyono A. 2012. Analisa pengaruh kepemimpinan, motivasi dan budaya organisasi terhadap kinerja dosen dan karyawan di Universitas Pawyatan Daha Kediri. Jurnal Ilmu Manajemen 1(1):283298.

Djati SP. 2000. Dampak pergeseran nilai-nilai organisasi terhadap kebijaksanaan sumber daya manusia dan implikasinya. Jurnal Manajemen dan Kewirausahaan 2(1): 9-18.

Elina M. 2011. Pengaruh motivasi dan kepemimpinan terhadap pegawai pada PT (Persero) Pelabuhan Indonesia II Cabang Panjang Bandar Lampung. Jurnal Organisasi Manajemen 1(1):49-58.

Ernawati, Ambarini. 2010. Pengaruh hubungan kerja dan lingkungan kerja terhadap kinerja pegawai dengan motivasi kerja sebagai variabel moderating.Jurnal Ekonomi dan Kewirausahaan 10(2):100-112. https://doi.org/10.17509/jimb. v2i1.13083.

Gardjito AH, Musadieq MA, Nurtjahjono GE. 2014. Pengaruh motivasi kerja dan lingkungan kerja terhadap kinerja karyawan (studi pada karyawan bagian produksi PT Karmand Mitra Andalan 
Surabaya). Jurnal Administrasi Bisnis 3(1):1-8.

Ghozali I. 2011. Stuctural Equation Modelling, Metode Alternatif dengan Partial Least Square. Semarang: Badan Penerbit Universitas Diponegoro.

Hair JF, Black B, Babin B, Anderson RE. 2010. Multivariate Data Analysis. New Jersey: Pearson Prentice Hall.

Kustrianingsih MR, Minarsih MM, Hasiholan LB. 2016. Pengaruh motivasi kerja, kepemimpinan, dan iklim organisasi terhadap kinerja karyawan pada Dinas Kebudayaan dan Pariwisata Kota Semarang. Journal of Management 2(2):1-15.

Mahendra IGNT, Brahmasari ID. 2014. Pengaruh kepemimpinan terhadap disiplin kerja, motivasi kerja dan kinerja perawat pelaksana di ruang rawat inap RSJ Menur Surabaya. Jurnal Ilmu Ekonomi dan Manajemen 1(1):22-42.

Mitchell TR. 1978. People in Organization (Understanding Their Behavior). New York: Mc Graw.

Moulana F, Sunuharyo BS, Utami JN. 2017. Pengaruh lingkungan kerja terhadap kinerja karyawan melalui variabel mediator motivasi kerja (studi pada karyawan PT Telkom Indonesia Tbk Witel Jatim Selatan). Jurnal Administrasi Bisnis 4(1):178-185. https://doi.org/10.35137/jmbk. v4i2.38.

Munparidi. 2012. Pengaruh kepemimpinan, motivasi, pelatihan dan lingkungan kerja terhadap kinerja karyawan Perusahaan Daerah Air Minum Tirta Musi Palembang. Jurnal Orasi Bisnis 7(1): 4754.

Parlinda V, Wahyudin M. 2009. Pengaruh kepemimpinan, motivasi, pelatihan dan lingkungan kerja terhadap kinerja karyawan pada Perusahaan Daerah Air Minum Kota Surakarta. Jurnal Ekonomi Universitas Muhammadiyah 3(6):1-16.

Prakoso RD, Astuti ES, Ruhana I. 2014. Pengaruh lingkungan kerja terhadap motivasi kerja dan kinerja karyawan (studi pada karyawan PT. AXA Financial Indonesia Cabang Malang). Jurnal Administrasi Bisnis 14(2):1-10.

Raykov T. 1997. Estimation of composite reliability for congeneric measures. SAGE Journals 21(2):173-184. https://doi. org/10.1177/01466216970212006.

Renat H. 2013. Pengaruh kepemimpinan dan motivasi kerja terhadap kinerja pegawai di Dinas Perhubungan Komunikasi dan Informatika Provinsi Sumatera Barat. Jurnal Pendidikan Ekonomi 2(1):1-11. https://doi.org/10.21009/ econosains.0111.06.

Sedarmayanti. 2017. Tata Kerja dan Produktivitas Kerja Aspek Ergonomi atau Kaitan Antara Manusia dengan Lingkungan. Bandung: CV Mandar Maju.

Suddin A, Sudarman. 2010. Pengaruh kepemimpinan, motivasi dan lingkungan kerja terhadap kinerja pegawai Kecamatan Lawetan Kota Surakarta. Jurnal Manajemen Sumberdaya Manusia $4(1): 1-8$.

Sugiyono. 2014. Metode Penelitian Manajemen. Bandung: Alfabeta.

Sukmasari H. 2015. Pengaruh kepemimpinan, motivasi, insentif, lingkungan kerja dan kepuasan kerja terhadap kinerja pegawai Dinas Pengelolaan Keuangan dan Aset Daerah Kota Semarang [tesis]. Semarang: Universitas Dian Nuswantoro. 